\title{
COOPERATION BETWEEN PHYSICIANS AND ADVISORY SERVICES IN A VOCATIONAL REHABILITATION CENTRE
}

\author{
By T. HuBER \\ Berufsfoerderungswerk Heidelberg, Germany
}

Abstract. The importance of cooperation between physicians and all other services in vocational rehabilitation is shown by demonstration of three follow-up studies. Vocational rehabilitation is understood as a new dimension in the therapy of disabled people.

Key words: Vocational rehabilitation; Paraplegic disabled people; Cooperation of allied professions.

\section{Introduction}

THE idea of vocational rehabilitation dates back to 1780 , when the French physician J ean André Venel first required trained specialised staff to instruct and teach their subjects besides medical care and apparative fitting. He was able to achieve this goal at his hospital (Fichtner, 1970).

Howard Rusk gave a paper in 1975 entitled 'Dynamic rehabilitation of neurologically induced physical disabilities', wherein he wrote: 'Patients develop a hope which is based on facts not on words alone. We find that those who master their disability with courage and their own hard work, and who are able to resume normal life, have such a profound feeling of which an average person has no knowledge' (Rusk, 1975).

Here we realise that even we physicians must learn to think in new dimensions when cooperating with all the other services in rehabilitation.

Behrendt (1975) has given the following two theses: ' $I$. Rehabilitation is an applied science. Applied on human beings, this science develops into an art. 2. Rehabilitation is a mission. This mission corresponds with philosophy and is humanism at the same time.' This means that we have to make these views our business. Behrendt's definition of rehabilitation is: 'The science of developing all resources necessary for a life to be worth living in a situation, where disability is a key factor.

The purpose of my paper will be to define the problems encountered by us in Heidelberg. You all know that the earlier rehabilitation measures are started, the more effective they are. It is interesting that Behrendt (1975) means that 'Rehabilitation is most effective, if personal drive is stimulated or if the drive is instilled from outside'.

\section{Materials}

In our vocational rehabilitation centre at Heidelberg-Wieblingen we have about I600 disabled people undergoing vocational resettlement. These I600 disabled have various forms of disabilities of the most varied severity. About Io per cent are wheelchair users, of which 35 are paraplegics and I 5 tetraplegics.

All our teaching programmes are tightly organised and aimed at reducing the stay at the centre to the shortest possible period of time. Nearly all disabled live in residential homes at our centre. Our teaching lessons begin at 7.30 in the morning 
and they end about 3.00 p.m. Afterwards the disabled have to do their homework. The problems facing the spinal cord injured are to be found early in the morning, not only in the afternoon.

Sir Ludwig's demand 'to give help to promote self-help' is one of the essentials without which we cannot do in rehabilitation. Our ward-nurses don't always have the time to wait until the disabled has dressed himself, because he got up late and is obliged to appear punctually in his classroom. So the nurse begins giving a little help, which leads gradually to the disabled growing accustomed to such help followed by a growing dependency and a loss in the standard of training. The 'stress' of lessons, examinations and the necessity to learn a great deal within a short period of time, brings along another problem, that despite the wide choice of accompanying therapy, in the form of physiotherapy and occupational therapy including all kinds of sports for disabled, these facilities are not sufficiently used by our disabled, the only exception being during the first weeks or months of their stay.

The absolutely necessary physiotherapy, especially for paraplegics and tetraplegics, is neglected, since it appears that they would not have enough time for it because one of the instructors might have said that instruction should have absolute priority. It is often enough forgotten, that sports give the chance to form new social contacts, even more so, than in the classroom.

It is true that in a vocational rehabilitation centre instruction and training have precedence. However, the necessity of accompanying therapy must be taken into consideration and provision must be made for it when setting up a new teaching programme.

This is the first step on our way to cooperation, where physicians should ensure that the disabled obtain optimum care, and where allowance should be made in favour of vocational training. We are concerned to respect 'the dignity of the human being', as the German philosopher Immanuel Kant put it (Lauenstein, I976), so that disabled people do not develop into an object of vocational rehabilitational purposes. Accordingly, we see vocational rehabilitation not only as one step in the effort to integrate the disabled, but view it as a part of an allround therapeutic aspect.

The distribution of duties in a vocational rehabilitation centre allows the physician to be present in all units, time allowing. He can be there seeking advice or as an advisor. He seeks advice when, as in the case of differential diagnosis or other problems of the disabled, he wants to know the opinions of the rehabilitation councillor, instructors, psychologists or resettlement officers, to enumerate only some of the advisory services in vocational rehabilitation.

He can be advisor as a 'primus inter pares' (Meinecke, I975; Wiedemann, 1977) whenever the rehabilitation team, which includes the physician as a coordinator (Cibeira and Liendo, 1972) and the disabled person as an integral figure, has difficulties and discussions of individual cases are necessary.

Now I want to introduce some of our advisory services. The rehabilitation councillor holds, in the case of a smoothly running rehabilitation process, the key position, since he knows best of all the various relationships of the disabled in his socio-cultural environment.

As far as I know, Patterson was the first to point this out in 1958 and 1959. He also coined the term that rehabilitation must be client-orientated, when he said: 'The client is the centre-point' (Patterson, 1958). Important to me seems his statement, that the 'conception of the client's independence' should be preserved by all the professional groups in vocational rehabilitation (Patterson, 
I959). They are all called to place more emphasis on the self-sufficiency and on the psychological and physical independence of the disabled, something mentioned by Meinecke (1965) and Wiedemann (1976). The functions of the rehabilitation councillor are divided into (I) specialised duties, such as coordination (network manager), guidance and assistance, communication-person, and organisation of leisure-time and sports, which are performed through his (2) professional activities, such as planning the reception, reception of the disabled, guidance through the professional training, and follow-up and resettlement. The last item mentioned is carried out mostly by specialised resettlement officers with us.

These staff members represent the first contact in the preliminary talks between the disabled and the future employers. They prepare the ground as far as possible to facilitate the separation from the vocational rehabilitation centre, which too often looks like a garden of Eden in comparison to the working conditions found outside.

The resettlement officers inspect the conditions at the working place, as far as sanitation, accessibility and adaptions are concerned, in order to exclude possible failure in the placement of the disabled person.

The psychological service is well staffed in our centre and completely integrated in the care of disabled. Papers on problems such as 'Consequences of the wheel-chair dependence on the psychological self-image' (Janzowski, I977) show their intensive interest in this group of disabled, although their conclusions are not quite convincing.

The testing of specialised forms of behaviour therapy shows first positive aspects, but does not allow any final conclusions, as yet. The co-workers in sociotherapy work hand in hand with the psychological service and the physicians on the social reintegration. Some overlapping and clashing is inevitable but in any case should provide a feedback, though we think that it should not be allowed to delegate the specific responsibility of the physician, because this responsibility in indivisible (Wiedemann, I977). At all events, all staff members of the team should always be aware of the fact that overcoming the disability depends solely on the disabled person.

The ideal striving for a continuous rehabilitation process has not yet been realised and years may intervene between the end of the medical rehabilitation and the beginning of vocational training. On the other hand, unfortunately, we see insufficiently stabilised disabled persons coming to the vocational rehabilitation centre, because some well-intentioned persons want to accelerate the rehabilitation process. This fact is contrary to the opinion of Fichtner (1970), who said 'the medical rehabilitation represents in principle the basis for sensible planning vocational rehabilitation, because a greater mobility increases the possibilities of qualified vocational training'.

Both methods, the too early one as well as the too late insertion into vocational rehabilitation, involve considerable risks for the disabled.

We can conclude that in testing a disabled person's rehabilitative ability, we must assume that 'it would be no solution to choose an occupation for a disabled person which would never enable him to compete with able-bodied people' (Peters, 1963). The vocational rehabilitation must be orientated, especially, today, towards the labour market in order to enhance the resettlement chances. Once more I want to point out that I agree with Dr Jenning, who considers that 'a new dimension in therapy vocational rehabilitation is on par with preventive, pharmacological and surgical measures' (Jenning, I974).

Before I start discussing our own problems by demonstrating three follow-ups, 
I want to provide a short review of papers, published in Paraplegia which deal with our subject.

\section{Review of the Literature}

Cibeira (1972) gave a report on: 'Team approach to the psychological treatment of patients with spinal cord injuries', in which he spoke of about 6I 5 patients in an accident hospital with emphasis on information of the patient concerning the repercussion of his injury and the overcoming of anxiety. He stated: 'The co-ordinator (medical doctor) acted as the link between the different members of the team until the leading position became functionally filled by those members who had, at that time, a closer contact with the patient'.

Johnson and co-workers were especially active in the social reintegration with their paper: 'Problems of social integration of paraplegics in Scotland' (Johnson, I972). The role of the disablement resettlement officer (D.R.O.) was illustrated and the willingness to contact the D.R.O. was mentioned.

Knuttson and co-workers (1973) gave a basic report on physical fitness and conditioning in paraplegic patients. With ergometers the authors could show that a real training can increase the level of performance about 50 per cent. This fact supports our demand to allow enough time for physical training through physiotherapy and sports in spite of the priority which learning has in a vocational rehabilitation centre.

Forner (1976) published: 'Social and working conditions of our paraplegics' concerning 160 patients in the rehabilitation centre in Valencia, Spain, of whom 64.4 per cent had incomplete lesions and only 35.7 per cent had regular employment.

\section{Case Histories}

Patient No. I: A man, born in I95I, suffered a complete lesion below Tro after a myelitis following a smallpox vaccination during his military service in the German army in I97I. In January 1974 he had his first profession-oriented testing at Heidelberg and in October 1974 he started his special course in industrial administration. On several occasions he spent some weeks in our rehabilitation hospital because of decubital ulcers. September 1975, first break-off of rehabilitative measures with recommendation to come back after his health had stabilised. January 1976, second start here-once again for months ill at home because of decubital ulcers. February 1977, end of vocational training with the recommendation to enter a special spinal unit for surgical treatment.

The decision to break off training was reached with the cooperation of teachers, rehabilitation-councillors and physicians.

Patient No. 2: A male paraplegic with complete paralysis below $\mathrm{T} 9 / \mathrm{Io}$ failed in his special training as machine construction engineer after 8 months because of alcohol abuse. A 6-month detoxication cure followed. Training resumed, he failed once more after 10 months because of his increasing absenteeism from the lessons and the growing intake of alcohol.

Here multiple special conferences were held, with and without the disabled, always with the entire team. Efforts of all staff members had been fruitless in giving a positive motivation to this paraplegic disabled.

Meinecke (1965, I977) mentioned the 'Pre-morbid personality and its great influence'. Also Sir Ludwig Guttmann once said, here I quote Meinecke (I965): 'It cannot be supposed that a man, who is unwilling to work, will be motivated to work by the fact that he got a spinal injury'. 
With the demonstration of this case we want to indicate that a lack of self-discipline, which can become apparent even in bad and insufficient bowel regulation, limits the team's efforts since the disabled is unable to master his problems by himself.

A well planned and well conceived health education, understood as information and programmed teaching on general and individual problems concerned with the special situation of each disabled person should be established with the team's cooperation. We are trying to take the first steps in this direction.

The head of our nursing staff suggested founding a special reception centre for those disabled who cannot find work or are unable to return home because of the severity of their disability even after successful vocational rehabilitation.

Patient No. 3: A man born in 1942 suffered complete paraplegia below $\mathrm{T}_{5}$ as a result of multiple gunshot wounds. Injury of the urethra with following abscesses to scrotum, one suicide attempt and a 3-year stay in a home for aged people characterise the history before coming to Heidelberg in 1977. He was persuaded by one of our physiotherapists to see me because, during physiotherapy, noises in his left hip joint and suspicion of subluxation as well as pains in the lower left area of his abdomen were claimed. He told me that he had bowel movements only every 3 weeks. As was discovered later, he had a massive abuse of analgetics, as for example one bottle of Dipyrone (in GermanyNovalgin) daily. This analgetic substance can be obtained freely in our pharmacies. Also in this case there will have to be many conferences, and considerable efforts, by physicians and all other staff members, will have to be made to guarantee a successful rehabilitation procedure. The problem of pain in paraplegia and tetraplegia was referred to extensively by Michaelis in 1970 .

\section{Recent Research Results}

Our research group of sociology had carried out an investigation in 1974 by interviewing 672 disabled in our Heidelberg centre, not only paraplegics, which produced the following interesting results: "73 per cent had come to terms with their disability; 5 per cent were of the opinion that disability made life difficult to cope with; 45 per cent believed that their disability would remain steady in the future; 24 per cent expected a deterioration; 22 per cent expected an improvement. Nearly 50 per cent hoped for an improved social and vocational position after their rehabilitation; about 50 per cent thought that they could have carried on working in their old profession; I7 per cent would have liked to be trained in another profession; 3 per cent only would have been satisfied with a pension.'

Some weeks ago, an interview of Io 000 vocationally rehabilitated adults was published in Germany: ' 74 per cent were employed in their new profession after their reorientation; 58 per cent were, 2 years after the end of vocational measures, in full employment and 12 per cent were part-time employed; 50 per cent considered their new profession to be of a higher standard; 25 per cent considered it to be equivalent to the former job; Io per cent only looked upon their new profession as being lower than the former one' (Berufliche Rehabilitation, 1977).

We can see from this that until now we have no adequate system to assess capacities and inclinations of the disabled in such an objective way, so that failures in planning and selection can be excluded. As Meinecke (1975) pointed out, it is psychologically extremely serious for the disabled to see that he is going in the wrong direction, as well as for the organisation which has to pay for a second rehabilitation process. This is evidenced by the following: 'In 1975 in our Heidelberg centre, out of 993 disabled, I30 had to be moved elsewhere in a new training programme; 93 had to give up training for health reasons; and 48 interrupted training for a shorter or longer period, so that only 671 out of a total of 993 successfully finished their courses' (Jahresbericht, I975). 
One more point which speaks in favour of cooperation, though rather alien to us physicians, is to familiarise oneself with the terms and the terminology of administration, as for example cost-benefit analyses. Economic restrictions influence more and more the chances of resettling rehabilitated disabled persons. In times of strict money control for the public health service, medical work does not remain unaffected. One cost-benefit analysis of January 1977 made at our centre in Heidelberg shows that after successful rehabilitation in a vocational rehabilitation centre a Io-year period of employment in the new profession gives a cost-benefit ratio of $\mathrm{I}: 5$.

\section{Conclusion}

The activities of the rehabilitation team do not end at the door of the vocational rehabilitation centre, when the disabled leaves after a successfully completed training. We all, the physician included, care about what happens afterwards as regards lodging, job and so on. But we must create a better follow-up system than we have at the moment in order to fulfil our task of socially integrating the rehabilitated disabled into the community. This system requires that architectural barriers as well as prejudice be removed by intensifying the education of the public through public relations work.

Summarizing, I want to point out that in my opinion the physician can be the competent speaker of all team members. It seems to be self-evident that all our engagement for the 'dignity of the human being' and the uniqueness of a man's personality requires to be intensified, and it is our job to strive with the rehabilitation team in this direction. The vocational training of disabled, especially the spinal cord injured, must not be carried out to the disadvantage of the level of training or of self-sufficiency. The practical science of rehabilitation can grow into an applied art for men, so that Sir Ludwig Guttmann's statement 'from a cripple to a tax-payer' can be widened to include an active participation in our modern society by means of successful rehabilitation and success achieved by rehabilitated disabled persons.

\section{SUMMARY}

Report on the necessity of cooperation between physicians and all the allied services in the vocational rehabilitation of disabled people regarding, especially, paraplegic disabled.

Demonstration of three follow-up studies.

Indications towards the necessity of accompanying therapy and health education as one part of the instructions are given.

\section{RÉSUMÉ}

L'importance de la cooperation entre les médecins et les autres groupes engagé dans la réadaptation professionel dans un grand centre de réeducation professionel est decrit à l'exemple des paraplegiques.

Demonstration des trois histoires de paraplegiques.

La necessité d'une programme de physiotherapie et du sport accompagnant les études et d'une education pour la santé est remarqué.

\section{ZUSAMMENFASSUNG}

Bericht über die Notwendigkeit einer engen Zusammenarbeit zwischen Ärzten und beratenden Diensten in der beruflichen Rehabilitation Behinderter am Beispiel Querschnittgelähmter. 
Demonstration von drei Fällen.

Hinweise auf die Notwendigkeit einer Gesundheitserziehung als Teil des Lernprogrammes und die Wichtigkeit der ausbildungsbegleitenden Therapie.

\section{REFERENCES}

BeHRENDT, R. C. (1975). Neurologische Rehabilitation als Wissenschaft und Aufgabe. Festschrift deutsche Gesellschaft für Neurologie, 17-20.

BEHRENDT, R. C. (1977). Berufliche Rehabilitation/Erfolgsbeobachtung. Sozialpolitische Umschau, 65-quoted after Informationsspiegel der Stiftung Rehabilitation, Heidelberg, $3,2$.

Cibeira, J. \& Liendo, E. G. (I972). Team approach to the psychological treatment of patients with spinal cord injuries. Paraplegia, ro, 85-90.

FICHTNER, H. J. (I970). Aspekte beruflicher Rehabilitation aus der Sicht des Orthopäden an einem Berufsförderungswerk. Landarzt, 46, 972-977.

Forner, J. F., Miro, R., MANTEIGA, A., SuAREZ, J. \& SERRA, M. (1976). Social and working conditions of our paraplegics. Paraplegia, 14, 74-80.

Forner, J. F., Miro, R., ManTeiga, A., SuAREZ, J. \& SERra, M. (1975). Fahresbericht der Stiftung Rehabilitation, Heidelberg.

JANZOWSKI, F. \& OESTERWITZ, J. (I977). Auswirkungen der Rollstuhlabhängigkeit auf die psychologische Selbstdarstellung. Zschr. Rehabilitation, in print.

Jenning, A. (1974). Probleme bei der beruflichen Rehabilitation. Therapiewoche, 24, 8I4-8I6.

Johnson, G. S., Johnson, R. H. \& Bowie, G. (1972). Problems of social integration for paraplegics in Scotland. Paraplegia, 10, I26-133.

Knuttson, E., Lewenhaupt-Olsson, H. \& Thorsen, M. (1973). Physical work capacity and physical conditioning in paraplegic patients. Paraplegia, 11, 205-216.

Knuttson, E., Lewenhaupt-Olsson, H. \& ThORSEN, M. (I977). Kosten-Nutzen-Analyse der beruflichen Rehabilitation. Informationsdienst für Fachkräfte der Rehabilitation. Stiftung Rehabilitation, Heidelberg, I, 2-IO.

Lauenstein, D. (1976). Die 'Würde des Menschen' bei Arzt und Patient. Deutsches Arzteblatt, 2 173-21 78.

MeIER, A. (I973). Ausbildungsbegleitende Psychotherapie. Eigenverlag Stiftung Rehabilitation, Heidelberg, I. Edition.

MeINECKE, F. W. (I965). Soziale und psychologische Fragen bei Querschnittgelähmten. Zentralblatt für Chirurgie, 25, $951-963$.

MeINECKE, F. W. (1975). Rehabilitation aus medizinischer Sicht. Kompass, 6, I94-I98.

MEINECKE, F. W. (I977). Rehabilitationsfragen aus klinischer Sicht. Orthopäde, 6, 85-91.

MiChAELIS, L. S. (I970). The problem of pain in paraplegia and tetraplegia. Bull. N.Y. Acad. Med., 46, 2, 80-96.

Patterson, C. H. (I958). Die Verantwortlichkeit des Beraters in der Rehabilitation, Bibliography unknown.

Patterson, C. H. (I959). Beratung als eine Beziehung. Fourn. of rehabilitation, 25, 6.

Peters, J. (1963). Rehabilitation als unteilbare Aufgabe. Zschr. Rehabilitation, 20-25.

PETERS, J. (1975). Rehabilitation im Berufsförderungswerk Heidelberg aus der Sicht der Behinderten. Informationsdienst für Fachkräfte der Rehabilitation. Stiftung Rehabilitation, Heidelberg, Vol. I I and I2.

Rusk, H. A. (1975). Dynamische Rehabilitation bei neurologisch bedingten Körperbehinderungen. Festschrift deutsche Gesellschaft für Neurologie, Hamburg, I.

WiEDEMANN, E. (1976). Wandel im Rehabilitationsdenken in den letzten Jahrzehnnten. Vortrag vor dem Kongress der deutschen Vereinigung fïr die Rehabilitation Behinderter, Mannheim, 8.10.1976, in print.

WiedemanN, E. (I977). Der Arzt in Rehabilitationsteam-Primus inter pares? Medizin Mensch, Gesellschaft, in print. 